IP Periodica Polytechnica

Transportation Engineering

47(3), pp. 213-219, 2019

https://doi.org/10.3311/PPtr.11166

Creative Commons Attribution (i)

RESEARCH ARTICLE

\section{Direction of the Corporate Culture in Slovak and German Transport Companies from a Top Managers' Perspective}

\author{
Rudolf Kampf ${ }^{1}$, Miloš Hitka², Lenka Ližbetinová ${ }^{3 *}$
}

Received 21 June 2017; accepted 12 June 2018

\begin{abstract}
The objective of the paper is to compare the level of corporate culture in Slovakia and Germany. Top managers of large transport companies were asked to participate in our research. Following the analysis, hierarchy corporate culture, with dominant features such as keeping within rules, regulations, was preferred in Slovak companies. Top Slovak managers asked for following this trend in the future. Clan corporate culture was the most used at present time as well as most preferred in following 5 years in Germany. Top German managers focused on employee's needs and employee's development. Our recommendation for top German managers is to remain in this trend. For top Slovak managers we propose to change their perception and to consider employees as a key factor. Employees are owners of new creative ideas through which enterprises can build their competitive advantage.
\end{abstract}

\section{Keywords}

corporate culture, transport companies, top managers, chi-square statistic

\footnotetext{
' Department of Transport and Logistics,

Faculty of Technology,

The Institute of Technology and Business in České Budějovice,

370 01, České Budějovice, Okruzni 10, Czech Republic

${ }^{2}$ Department of Business Economics,

Faculty of Wood Sciences and Technology,

Technical University in Zvolen,

960 53, Zvolen, T.G. Masaryka 24, Slovakia

${ }^{3}$ Department of Field Didactics,

Faculty of Technology,

The Institute of Technology and Business in České Budějovice,

370 01, České Budějovice, Okruzni 10, Czech Republic

"Corresponding author, e-mail: lizbetinova@mail.vstecb.cz
}

\section{Introduction}

Nowadays, we are witnessing the deep structural changes in Europe. Globalization processes determine not only transport but also all human activities (Šulgan, 2006). In turbulent changing business environment only those companies that understand the current trends in global economy may survive (Stopka et al., 2015; Mura and Gašpariková, 2010; Li and Jiang, 2016). To be able to react to this situation as well as to ensure the sustainability and continuous development and due to the tough competition, managers strive to build in their enterprises a functioning process because business entities have to achieve efficiency in their processes (Čambál and Caganova, 2010; Urbancová and Fejfarová, 2017; Němec et al., 2015). Companies must invest great effort in development of management system that will ensure their survival on the market (Klarić et al., 2015; Plchová and Turáková, 2016). This is the condition under which the firm is successful (Myšková, 2001). According to Stopka et al. (2015) the quality is an important tool for customer retention and it also has effects on the performance and economic results of the organization in the competitive environment. Based on Kucharcikova et al. (2016) human capital management helps enterprises achieve enterprise goals just by using the human capital efficiently. Human resources present strengths and competitive advantages of companies (Stacho and Stachová, 2013; Hrmo et al., 2012). Enterprise success is affected not only by employee and their performance but also by approaches and values appreciated by employees as well as by employee behavior in and outside the workplace, it means corporate culture (Lorincová et al., 2016; Vetráková et al., 2016). Corporate culture is traditionally considered to have an important influence on an organization's effectiveness (Deal and Kennedy, 1982; Schein, 1990; Wilkins and Ouchi, 1983), and in recent review of the literature, some culture orientations have a positive effect on performance measures (Sackmann, 2010). Peters and Waterman (1982) were possibly the first authors telling managers that having a strong culture was a key to organizational success. Cameron and Quinn's (2006) premise is that strong organizational culture is a key to corporate profitability. Corporate culture is an integral part of each enterprise (Turáková, 2016). 
It is the set of key values, beliefs, norms, attitudes and preferences shared by members of an organization and passed down from one generation to the next (Daft, 2006; Weberová and Ližbetinová, 2016; Syafii et al., 2015). According to Jafari et al. (2013) organizational culture defines the collection of organization common values, belief and faith. It also contains competitiveness, social responsibility, support innovation and performance (Markova et al., 2017). Most discussions of organizational culture (Cameron and Ettington, 1988; O'Reilly and Chatman, 1996; Schein, 1996) agree with the idea that culture is a socially constructed attribute of organizations which serves as the "social glue" binding an organization together. Unfortunately, most people are unaware of their culture until it is challenged. Culture is undetectable most of the time because it is not challenged or consciously articulated. Organizations tend to develop a dominant orientation and value set - or organizational culture - over time as they adapt and respond to challenges and changes in the environment (Schein, 1996; Sathe, 1983). Measuring culture, therefore, has presented a challenge to organizational scholars and change agents (Cameron, 2008). Cameron and Quinn's (2006) diagnostic instrument has demonstrated reliability and validity and is therefore a useful tool for improving organizational culture (Cameron and Ettington, 1988; Fleenor, 2008; Trice and Beyer, 1993). The tool, the Organizational Culture Assessment Instrument (OCAI), was developed as a means for organizations to quantify organizational culture (Cameron and Quinn's, 2006). More importantly, OCAI results provide a means by which organizations can navigate organizational change successfully (Suderman, 2012). Corporate culture, which plays a subtle but pervasive role in organizational life, has important implications for managerial action.

\section{Methodology}

The objective of the paper is to compare the level of corporate culture in Slovakia and Germany. The research was conducted from February till May 2016 in 16 transport companies. 9 companies were operating in the Slovak market and 7 in the German market. Top managers working in large businesses (more than 250 employees) were asked to participate in the research. The sampling unit consisted of 198 respondents, 96 from Slovakia and 102 from Germany. More details are presented in Table 1. OCAI was used in the research. It is a psychometric tool developed which purpose is to help organizations identify their current and preferred culture (Wilkins and Ouchi, 1983).

Through the use of a research, participants identify their perceptions of both existing culture and their desired future culture. Organizations can then utilize these results to assess both the current and desired culture state. The OCAI instrument is built on Cameron and Quinn's competing values framework. The framework is rooted in considerable research in the field of organizational culture and aligns with well-accepted culture categorical themes - the way people think, their values, assumptions and

\begin{tabular}{|c|c|c|c|}
\hline \multirow{2}{*}{\multicolumn{2}{|c|}{ Data to identify respondents }} & \multicolumn{2}{|c|}{ Slovakia } \\
\hline & & Absolute & Relative \\
\hline \multirow{2}{*}{ Gender } & Male & 66 & 68.75 \\
\hline & Female & 30 & 31.25 \\
\hline \multirow{4}{*}{ Age } & Up to 30 years & 6 & 6.25 \\
\hline & $31-40$ years & 24 & 25.00 \\
\hline & $41-50$ years & 30 & 31.25 \\
\hline & 50 years and more & 36 & 37.50 \\
\hline \multirow{3}{*}{$\begin{array}{l}\text { Completed } \\
\text { education }\end{array}$} & Lower secondary & 12 & 12.50 \\
\hline & Upper secondary & 36 & 37.50 \\
\hline & Higher & 48 & 50.00 \\
\hline \multirow{5}{*}{ Seniority } & Less than 1 year & 0 & 0.00 \\
\hline & $1-3$ years & 12 & 12.50 \\
\hline & $4-6$ years & 0 & 0.00 \\
\hline & $7-9$ years & 12 & 12.50 \\
\hline & 10 years and more & 72 & 75.00 \\
\hline \multicolumn{2}{|c|}{ Data to identify respondents } & \multicolumn{2}{|c|}{ Germany } \\
\hline \multirow{2}{*}{ Gender } & Male & 60 & 58.82 \\
\hline & Female & 42 & 41.18 \\
\hline \multirow{4}{*}{ Age } & Up to 30 years & 30 & 29.41 \\
\hline & $31-40$ years & 48 & 47.06 \\
\hline & $41-50$ years & 0 & 0.00 \\
\hline & 50 years and more & 24 & 23.53 \\
\hline \multirow{3}{*}{$\begin{array}{l}\text { Completed } \\
\text { education }\end{array}$} & Lower secondary & 30 & 29.41 \\
\hline & Upper secondary & 48 & 47.06 \\
\hline & Higher & 24 & 23.53 \\
\hline \multirow{5}{*}{ Seniority } & Less than 1 year & 18 & 17.65 \\
\hline & $1-3$ years & 18 & 17.65 \\
\hline & $4-6$ years & 30 & 29.41 \\
\hline & $7-9$ years & 24 & 23.53 \\
\hline & 10 years and more & 12 & 11.76 \\
\hline
\end{tabular}

Source: authors

how they process information. The research revealed six key dimensions which formed the basis of their framework on organizational culture: dominant characteristics, organizational leadership, management of employees, organizational glue, strategic emphasis and criteria for success (Suderman, 2012). Based on the framework, the OCAI consists of six questions. Each question has four alternatives. The respondent divided 100 points among these four alternatives depending on the extent to which each alternative is similar to own organization. A higher number of points are given to the alternative that is most similar to own organization. For example, in first question, if someone think alternative $\mathrm{A}$ is very similar to own organization, alternative $\mathrm{B}$ and $\mathrm{C}$ are somewhat similar, and alternative D is hardly similar at all, one might give 55 points to $A, 20$ points to $B$ and $C$, and five points to $D$. In the first pass through the six questions, respondents answered six key dimensions from the perspective of what the organizational culture is currently like. In the second pass, respondents answered the same six key dimensions from the perspective of 
what their preferred organizational culture would be in the future. Total equals 100 points for each question. By completing the instrument in all six questions, it is possible to provide a picture of how organization operates and the values that characterize it (Jungnitsch et al., 2016; Schmidtová and Vacek, 2013). No right or wrong answers exist for these questions just as there is not right or wrong culture (Cameron and Quinn, 1999; 2006). Subsequently, survey results were processed by mathematical-statistical methods. A chi square $\left(\chi^{2}\right)$ statistic was used to investigate whether distributions of categorical variables differ from one another. The null hypothesis $\mathrm{H}_{0}$ was tested and compared with an alternative hypothesis $\mathrm{H}_{1}$ at predetermined alpha level of significance $(0.05)$ and degrees of freedom $(\mathrm{df}=3)$. In $\mathrm{H}_{0}$ we supposed that the distributions of Slovak and German respondents are equal. If $\chi^{2}>\chi_{0.05 ; \mathrm{df}=3}^{2}$, then $\mathrm{H}_{0}$ is rejected in favour of $\mathrm{H}_{1}$, which means that there are statistically significant differences between the distributions of Slovak and German respondents.

\section{Results and Discussion}

Based on the methodology of Cameron and Quinn(1999; 2006), dominant characteristics was the first dimension analysed. Fig. 1 compares current perception of dominant characteristics in Slovak and German transport companies. The results of the research presented in Fig. 1 show the alternative D was marked as the most dominant in Slovak transport companies. The organization is a very controlled and structured place. In the following 5 years alternative A was most preferred alternative by Slovak and German top managers working in transport companies. Friendly atmosphere should be dominant in the workplace.

Organizational leadership is presented in Fig. 3 and Fig. 4. Currently the organizational leadership in the Slovak transport organizations was considered to exemplify coordinating,

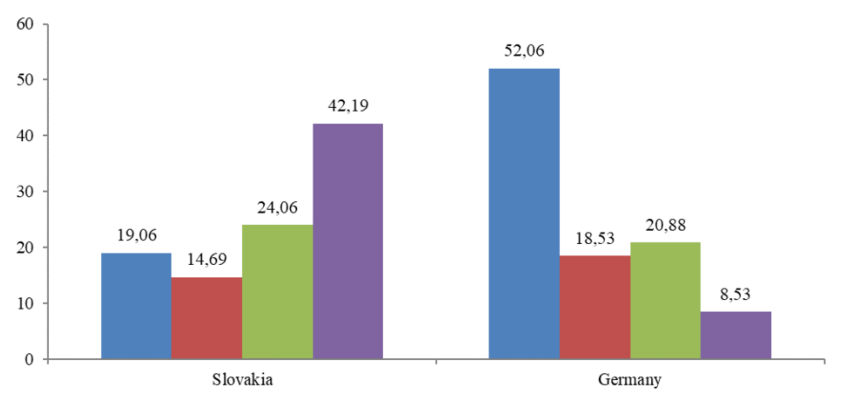

Fig. 1 Current dominant characteristics. Source: authors

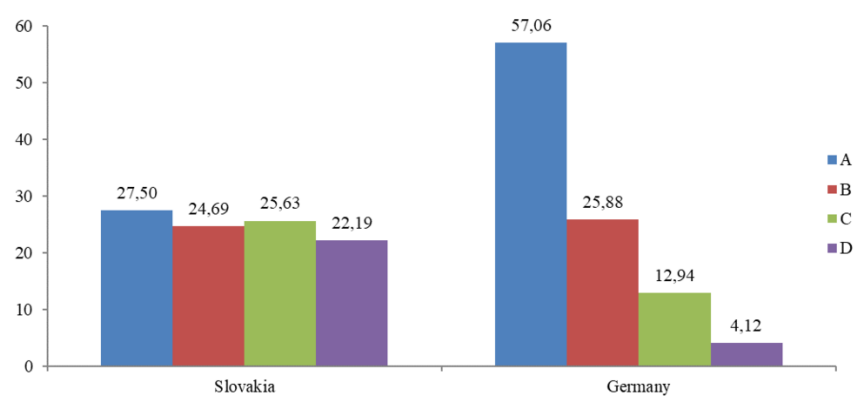

Fig. 2 Desired dominant characteristics. Source: authors

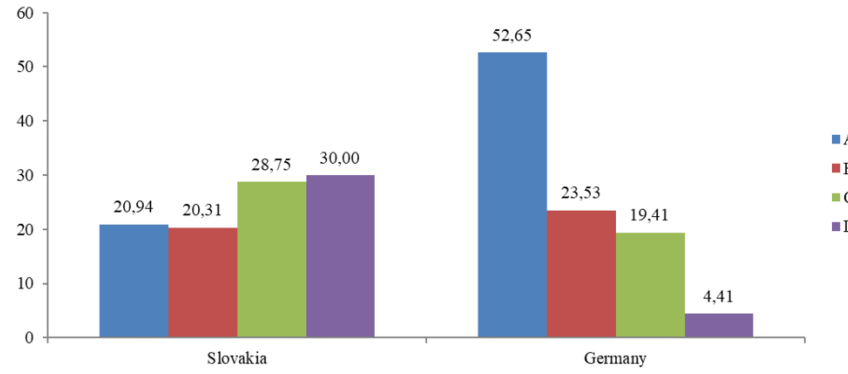

Fig. 3 Current organizational leadership. Source: authors

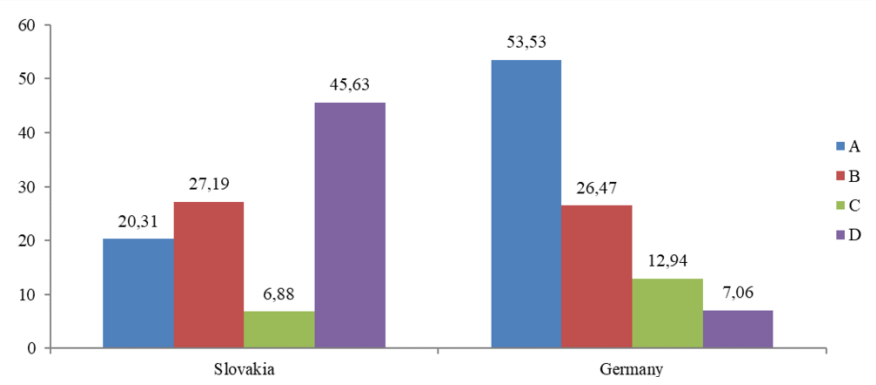

Fig. 4 Desired organizational leadership. Source: authors

organizing, or smooth-running efficiency. The alternative D was preferred at the present and future time by top Slovak managers of transport companies. However, there are differences compared to German respondents. Top German managers preferred alternative A as the most suitable at the present and future time. The leadership in the German transport organizations was considered to exemplify mentoring, facilitating, or nurturing.

The third studied area was the management of employees. Current perception is presented in Fig. 5. Fig. 6 identifies desired management of employees in the following 5 years. Based on the results, the majority of Slovak respondents chose alternative $\mathrm{C}$ for the present. The alternative focuses on achievement, and hard-driving competitiveness. Top managers of Slovak and German transport companies preferred alternative A as the most suitable for the future (Fig. 6). They chose mentoring and taking charge of business in term of organisational leadership.

Organization glue was the fourth key dimension analysed by methodology of Cameron and Quinn (1999; 2006). Results are illustrated in Fig. 7 and Fig. 8. From the point of view of top managers in Slovak transport companies the glue that currently holds the organization together was formal rules and policies. Maintaining a smooth-running organization was important. On the other hand top managers in Germany perceived the

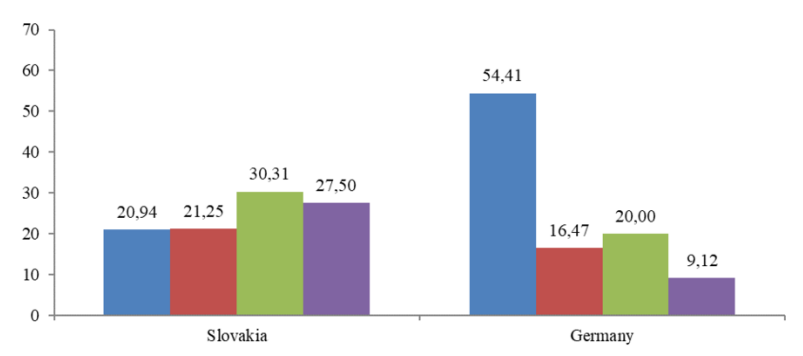

Fig. 5 Current management of employees. Source: authors 


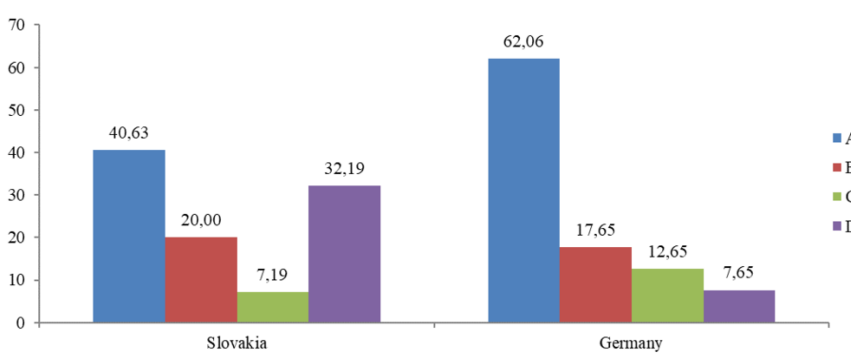

Fig. 6 Desired management of employees. Source: authors

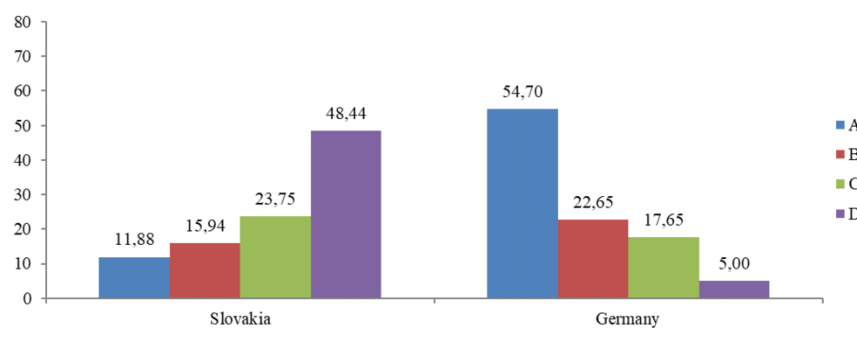

Fig. 7 Current organization glue. Source: authors

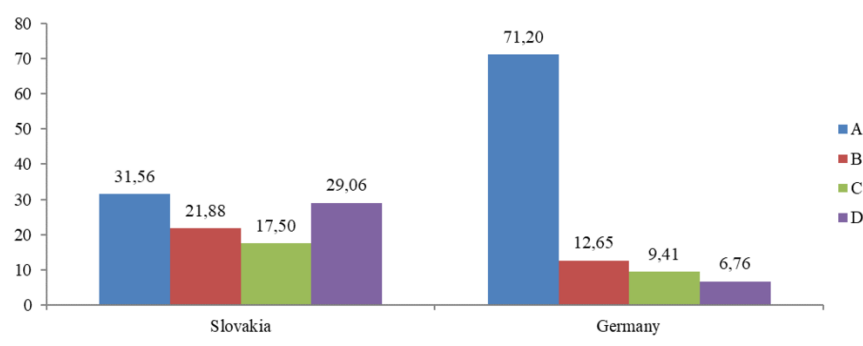

Fig. 8 Desired organization glue. Source: authors

corporate culture through the alternative A. According to the opinion of top managers in Germany as well as in Slovakia alternative A should dominate in the future. The emphasis should be put on loyalty and mutual trust.

In the area of strategic emphases, alternative $\mathrm{D}$, which emphasizes stability and enterprise functioning, dominated in Slovak transport companies in 2016. From the point of view of top Slovak managers presented in Fig. 9, performance, control and operating flexibility were the important factors for the achievement of the strategic goal. Managers asked for following this trend in the future (Fig. 10). However alternative A dominated in Germany. The German transport organizations emphasized human development. Similar trends should continue in following 5 years.

Results of criteria of success are illustrated in Fig. 11 and Fig. 12. Slovak organizations have defined success on the basis of efficiency (alternative D). Dependable delivery, smooth scheduling and low-cost production were critical. This trend was preferred in the future. German respondents identified the alternative $\mathrm{A}$ as the most used at present time as well as most preferred in following 5 years. The organization has defined success on the basis of development of human resources, teamwork, employee commitment, and concern for people.

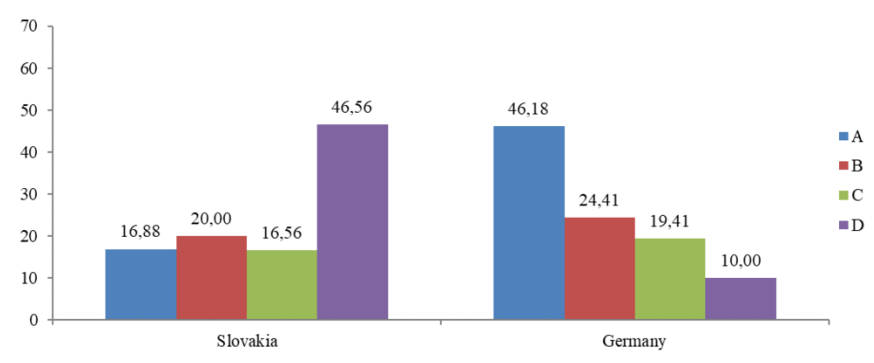

Fig. 9 Current strategic emphases. Source: authors

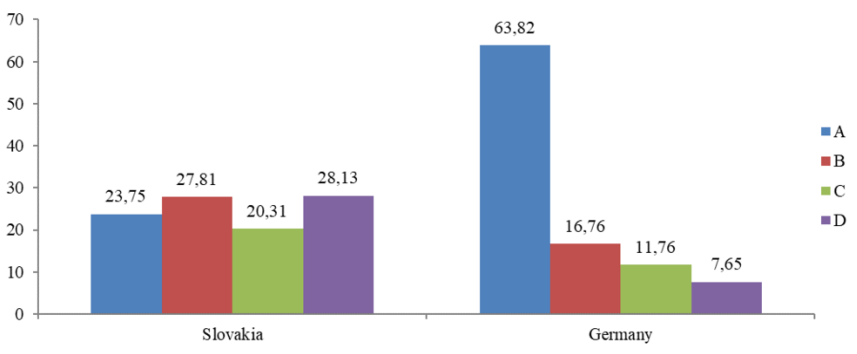

Fig. 10 Desired strategic emphases. Source: authors

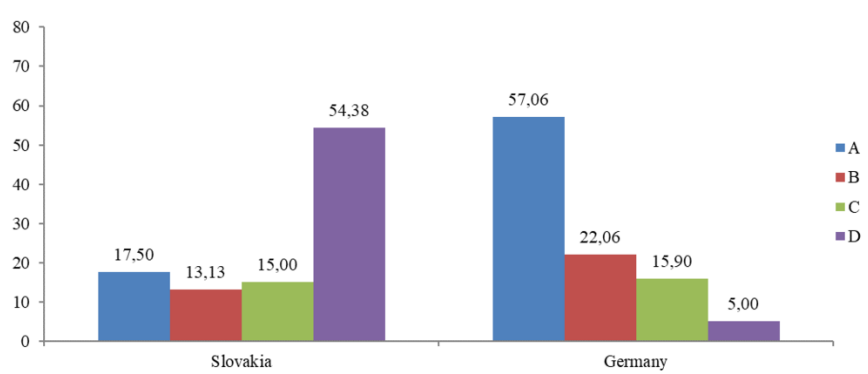

Fig. 11 Current criteria of success. Source: authors

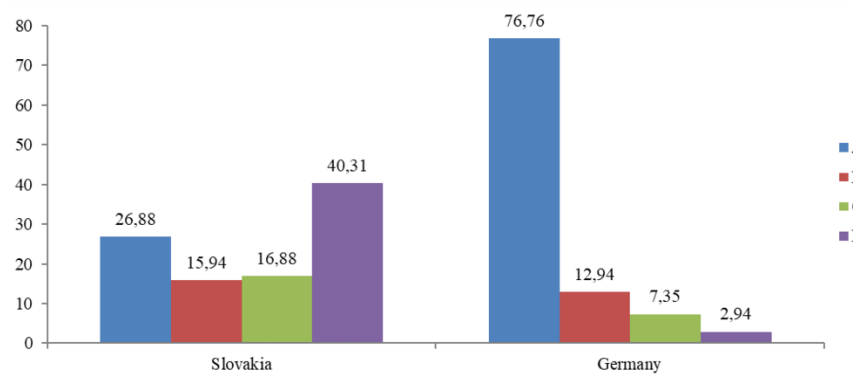

Fig. 12 Desired criteria of success. Source: authors

By completing the opinions of respondents in all six dimensions, it is possible to provide a profile of corporate culture (Fig. 13, Fig. 14). Following the outcomes, the hierarchy culture was dominant in 2016 in large Slovak transport companies (more than 250 employees). The hierarchy culture is characterized as a formalized and structured place to work. Procedures and well-defined processes govern what people do. Effective leaders are good coordinators, organizers, and efficiency experts. Maintaining a smooth-running organization is important. The long-term concerns of the organization are stability, predictability, and efficiency. Formal rules and policies hold the organization together (Cameron, 2008). From the point 
of view of top Slovak managers, this type of culture was preferred in following 5 years. Based on the research results, from the point of view of top German manager's clan culture was typical for large transport companies in Germany in 2016. The clan culture is typified as a friendly place to work where people share a lot of themselves. It is like an extended family with best friends at work. Leaders are thought of as mentors, coaches, and, perhaps, even as parent figures. The organization is held together by loyalty, tradition, and collaboration. Commitment is high. The organization emphasizes the long-term benefits of individual development with high cohesion and morale being important. Success is defined in terms of internal climate and concern for people. The organization places a premium on teamwork, participation, and consensus (Cameron, 2008). Top German managers asked for following clan culture in the future.

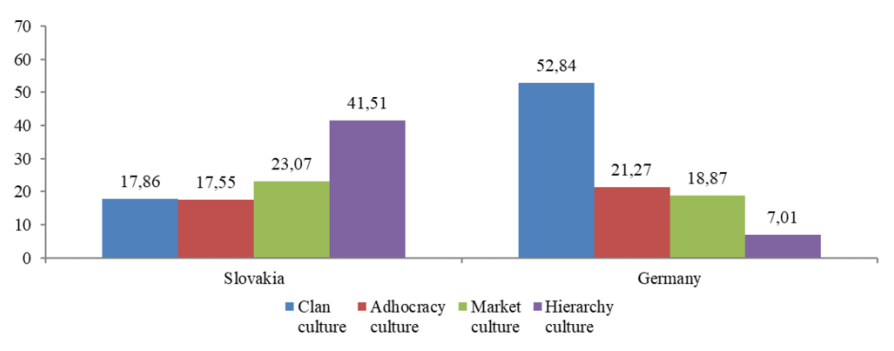

Fig. 13 Current corporate culture profile. Source: authors

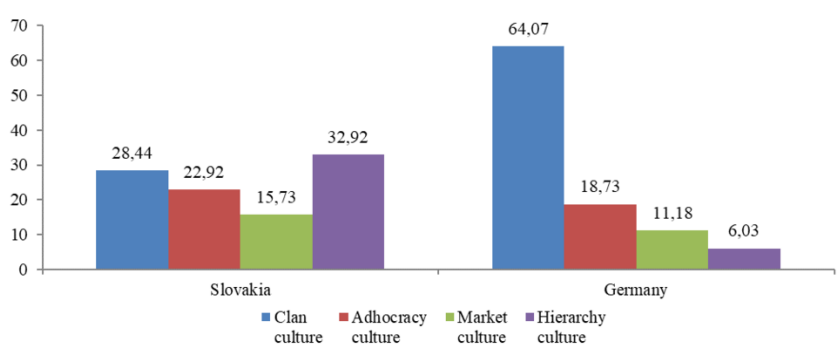

Fig. 14 Desired corporate culture profile. Source: authors

Following the analysis, the chi square $\left(\chi^{2}\right)$ statistic was used to investigate whether distributions of categorical variables differ from one another. At predetermined alpha level of significance (0.05) and degrees of freedom $(\mathrm{df}=3), \mathrm{H}_{0}$ is rejected as $\chi^{2}>\chi_{0.05 ; \mathrm{df}=3}^{2} \cdot\left(\chi_{0.05 ; \mathrm{df}=3}^{2}=7.81\right)$. Despite the fact that Slovak and German respondents agreed in some dimensions, based on the result presented in Table 2, we can conclude that there are statistically significant differences between the distributions of Slovak and German respondents in all six key dimensions analysed as well as in corporate culture profile. The differences may be caused by the diversity of national cultures and mentality of the people in analysed countries.

Fig. 13 presents that hierarchy culture dominated in Slovak transport companies in 2016. Similar outcomes are mentioned by Ližbetinová et al. (2016), Matraeva et al. (2016), Jaeger and Adair (2013), Hitka and Balážová (2013), Balogh et al. (2011)
Table 2 Results summary of the chi square $\left(\chi^{2}\right)$ statistic

\begin{tabular}{lcc}
\hline Dimensions & $\begin{array}{c}\text { Current situation in } \\
\text { Slovakia and Germany }\end{array}$ & $\begin{array}{c}\text { Desired situation in } \\
\text { Slovakia and Germany }\end{array}$ \\
\hline $\begin{array}{l}\text { Dominant characteristics } \\
\text { Organizational }\end{array}$ & 37.16 & 27.53 \\
leadership & 36.17 & 46.14 \\
Management of & & \\
employees & 26.70 & 22.21 \\
Organization glue & 64.29 & 32.99 \\
Strategic emphases & 38.18 & 34.60 \\
Criteria of success & 63.32 & 60.35 \\
Corporate culture profile & 41.95 & 34.09 \\
\hline
\end{tabular}

and Hitka and Czajkowska (2010). Authors cited point to the fact that the procedures, rules and regulations are crucial tools in the management of enterprises. From the point of view of top Slovak managers working in large transport companies, this trend should continue in the future. Hierarchy culture should dominate. Compared to our previous research, we can conclude that there are differences in the future direction of the corporate culture in small, medium and large transport companies. In the research conducted in 2015 in 14 logistics companies respondents asked for clan corporate culture in future under which a friendly working environment would be created (Ližbetinová et al., 2016). Firstly, difference can be caused by size of the company. Large businesses (more than 250 employees) participated in the research in 2016 while small and medium-sized companies were involved in the research in 2015. Secondly, the difference can be caused by the job position of analyzed respondents. In the research from 2015 we analyzed the opinions of all employees regardless of their position. In this research we focused mainly on top managers. From their position managers can see the direction of company differently. In addition, the opinions of Slovak and German top managers are different. Based on this research, clan corporate culture dominated to German transport companies. Similar outcomes are presented by Hitka et al. (2015). Top German managers asked for clan corporate culture in following 5 years. Our findings reflect the perception of human resources as one of the most important production factors, as technology, processes, and organizational structure can be copied, but the value that competent and dedicated employees can bring to companies cannot be easily taken away (Scholz and Bohm, 2008; Ahmad et al., 2012; Nedeliaková et al., 2017).

\section{Conclusions}

Corporate culture exists in every company. It is something like the personality of a company. But the presentation of corporate culture is underestimated externally. However, enterprises such as IBM, Sony, GM and others follow this trend, and pay attention to corporate culture, because it represents the quality of the company. The objective of the paper was to compare the level of corporate culture in Slovakia and Germany 
from a top managers' perspective. Top managers of large transport companies (more than 250 employees) were involved in our research. The sampling unit consisted of 198 top managers. The methodology of Cameron and Quinn was used. OCAI allowed us to know the corporate culture deeper in analyzed countries. Based on the research results, the direction of corporate culture by Slovak and German top managers is different. Rules, objectives, performance and standards are crucial in future for top Slovak managers. On the other hand, openness and devotion is linked to the management style of top German managers. Top managers in Germany focus on employees, their needs and development because they consider the employees as bearers of knowledge. We agree with the top German managers. If a company is interested in realizing their business as long as possible, for top Slovak managers we suggest to consider employees as a key factor because employees are owners of new creative ideas. Employees are the source of competitive advantage for business, rather than finance or the technology. If top Slovak managers change their perception, if the rules are not crucial for them but employees are key element for managers, then we can expect that satisfied employees will increase productivity as well as overall quality and efficiency of work done. It will be reflected in the overall success of the company in the market.

\section{Acknowledgements}

This research was supported by VEGA 1/0024/17 Computational model of motivation and APVV-16-0297 Updating of anthropometric database of Slovak population.

\section{References}

Ahmad, M. B., Wasay, E., Malik, S. U. (2012). Impact of Employee Motivation on Customer Satisfaction: Study of Airline Industry in Pakistan. Interdisciplinary Journal Of Contemporary Research In Business. 4(6), pp. 531-539. [Online]. Available from: http://journal-archieves24.webs. com/531-539.pdf [Accessed: 1st February 2017]

Balogh, Á., Szabó, L., Gaál, Z. (2011). Cultural Intelligence versus Organizational Culture. The International Journal of Diversity in Organizations, Communities and Nations. 11(1), pp. 223-236. https://doi.org/10.18848/1447-9532/CGP/v11i01/38966

Čambál, M., Caganova, D. (2010). Corporate Culture Influence on Effective Initialization and Application of Knowledge Management in Enterprises. In: Proceedings of the 11th European Conference on Knowledge Management, (EDKM 2010): Universidade Lusíada de Vila Nova de Famalicão, Famalicão, Portugal, Sept. 2-3, 2010. pp. 176-181.

Cameron, K. S., Ettington, D. R. (1988). The Conceptual Foundations of Organizational Culture. Working Paper \#544, The University of Michigan, School of Business Administration, Michigan, USA.

Cameron, K. S., Quinn, R. (1999). Diagnosing and Changing Organizational Culture: Based on the Competing Values Framework. 1st ed., Prentice Hall, New Jersey, USA.

Cameron, K. S. (2008). A Process for Changing Organizational Culture. In: Handbook of Organizational Development. (Cummings, T. G. (ed.)), pp. 429-445. Sage Publishing, Thousand Oaks, California, USA.
Cameron, K., S., Quinn, R. (2006). Diagnosing and Changing Organizational Culture: Based on the Competing Values Framework. Rev. ed., JosseyBass, San Francisco, California, USA.

Daft, R. L. (2006). Organization Theory and Design. South-Western Cengage Learning, Mason, Ohio, USA.

Deal, T. E., Kennedy, A. A. (1982). Corporate Cultures: The Rites and Rituals of Corporate Life. Addison-Wesley Publishing Company, Boston, Massachusetts, USA.

Fleenor, J. W. (2008). Making the Impossible Possible: Leading Extraordinary Performance, The Rocky Flats Story by Kim Cameron and Marc Levine. Personnel Psychology. 61(1), pp. 195-225.

https://doi.org/10.1111/j.1744-6570.2008.00111_5.x

Hitka, M., Balážová, Ž. (2013). The Use of Corporate Culture Principles in the Position of Facility Manager. In: Toyotarity, Management of Intellectual Values. (Borkowski, S., Rosak-Szyrocka, J., (eds.)), (Chapter 4), pp. 6085. Aeternitas Publishing House, Alba Iulia, Romania. [Online]. Available from: https://depot.ceon.pl/handle/123456789/3496 [Accessed: 1st February 2017]

Hitka, M., Czajkowska, A. (2010). Podnikova kultura ako zdroj konkurencnej vyhody podniku. (Corporate culture as a source of competitive advantage of enterprise.) Manažment v teórii a praxi. 6(4), pp. 11-21. (in Czech)

Hitka, M., Vetráková, M., Balážová, Ž., Danihelová, Z. (2015). Corporate Culture as a Tool for Competitiveness Improvement. Procedia Economics and Finance. 34, pp. 27-34.

https://doi.org/10.1016/S2212-5671(15)01597-X

Hrmo, R., Kučerka, D., Krištofiakovâ, L. (2012). Developing the Information Competencies via E-learning and Assessing the Qualities of E-learning Text, In: 15th International Conference on Interactive Collaborative Learning (ICL), Villach, Austria, Sept. 26-28, 2012. pp. 1-4.

Jaeger, M., Adair, D. (2013). Organisational culture of construction project managers in the GCC countries. Engineering, Construction and Architectural Management. 20(5), pp. 461-473.

https://doi.org/10.1108/ECAM-01-2012-0004

Jafari, S., Abbaspour, A., Azizishomami, M. (2013). The effect of organizational culture on the knowledge management implementation processes from the viewpoint of Education Dept employees. Interdisciplinary Journal Of Contemporary Research In Business. 5(1), pp. 237-245. [Online]. Available from: https://pdfs.semanticscholar.org/1009/d4c5dc1e069da23a748605c9b5ccba64324d.pdf [Accessed: 1st February 2017].

Jungnitsch, R., Stoffers, J., Neessen, P. (2016). Organizational Culture from an Internal and External Stakeholders' Perspective. American Journal of Applied Sciences. 13(6), pp. 748-753.

https://doi.org/10.3844/ajassp.2016.748.753

Klarić, K., Grladinović, T., Šegotić, K., Greger, K., Grošelj, P., Klarić, M. (2015). Identification of Key Factors of TQM: Application of AHP and PROMETHEE Methods. In: 26th International Conference on Wood Science and Technology (ICWST), Zagreb, Croatia, Oct. 16, 2015. pp. 127-134.

Kucharcikova, A., Konusikova, L., Tokarcikova, E. (2016). Approaches to the Quantification of the Human Capital Efficiency in Enterprises. Communications. 1A, pp. 49-54. [Online]. Available from: http://www3.uniza.sk/komunikacie/archiv/2016/1a/1a_2016en.pdf [Accessed: 1th February 2017]

Li, C. G., Jiang, G. H. (2016). The Impact of Resource from Science and Technological Projects on Firm Innovation: An Exploration through Echo Model Simulation. In: 3rd International Conference on Economic, Business Management and Education Innovation (EBMEI 2016), Prague, Czech Republic, May 10-11, 2016. pp. 153-159.

Ližbetinová, L., Lorincová, S., Caha, Z. (2016). The Application of the Organizational Culture Assessment Instrument (OCAI) to Logistics Enterprises. Naše More. International Journal of Maritime Science \& Technology. 63(3), (Special Issue), pp. 170-176. [Online]. Available from: http://www.nase- 
more.com/the-application-of-the-organizational-culture-assessment-instrument-ocai-to-logistics-enterprises/ [Accessed: 21st January 2017]

Lorincová, S., Schmidtová, J., Balážová, Ž. (2016). Perception of the Corporate Culture by Managers and Blue Collar Workers in Slovak Wood-Processing Businesses. Acta Facultatis Xylologiae Zvolen. 58(2), pp. 149-163. https://doi.org/10.17423/afx.2016.58.2.16

Markova, T., Glazkova, I., Zaborova, E. (2017). Quality Issues of Online Distance Learning. Procedia - Social and Behavioral Sciences. 237, pp. 685-691. https://doi.org/10.1016/j.sbspro.2017.02.043

Matraeva, L. V., Konov, A. A., Erokhin, S. G. (2016). Statistical Analysis of Key Criteria Identifying Corporate Cultures. International Review of Management and Marketing. 6(S1), pp. 307-311. [Online]. Available from: file://C:/Users/user/Downloads/1929-5504-1-PB.pdf [Accessed: 21st January 2017]

Mura, L., Gašpariková, V. (2010). Penetration of small and medium sized food companies on foreign markets. Acta Universitatis Agriculturae et Silviculturae Mendelianae Brunensis. 58(3), pp. 157-164. https://doi.org/10.11118/actaun201058030157

Myšková, R. (2001). Vliv lidského faktoru na vykonnost podniku. (Effect of human factor on enterprise performance.) Ústav ekonomie Univerzity Pardubice. (Scientific Papers of the University of Pardubice), 6, pp. 75-79. (in Czech) [Online]. Available from: http://hdl.handle.net/10195/32279 [Accessed: 1st February 2017]

Nedeliaková, E., Panák, M., Šipuš, D. (2017). Innovative Trends in Process-Oriented Quality Management within Railway Transport. Periodica Polytechnica Transportation Engineering. 45(2), pp. 84-89. https://doi.org/10.3311/PPtr.9582

Němec, F., Potkány, M., Lorincová, S., Raušer, D. (2015). A Proposal for the Optimization of Storage Areas in a Selected Enterprise. Naše More. International Journal of Maritime Science \& Technology. 62(3), (Special Issue), pp. 101-108. [Online]. Available from: http://www.nasemore. com/a-proposal-for-the-optimization-of-storage-areas-in-a-selected-enterprise/ [Accessed: 25th January 2017]

O'Reilly, C. A., Chatman, J., A. (1996). Culture as social control: Corporations, cults, and commitment. In: Research in Organizational Behavior: An annual series of analytical essays and critical reviews. (Staw, B. M., Cummings, L. L. (eds.)), 18, pp. 157-200. Elsevier Science/JAI Press, USA. [Online]. Available from: https://pdfs.semanticscholar. org/0409/734d24460ea25d868bb1ea9f534de3f067d2.pdf [Accessed: 24th January 2017]

Peters, T. J., Waterman, R. H. (1982). In Search of Excellence. 1st ed., HarperBusiness Essentials, New York, United States.

Plchová, J., Turáková, A. (2016). Budovanie značky zamestnávatel'a ako súčast' podnikovej kultúry - výskum trendov v Číne. (Employer branding as a part of corporate culture - research of trends in China.) MANEKO: MANažment a EKOnomika. (Journal of MANagament and ECOnomics.) 8(1), pp. 53-62. (in Slovak)

Sackmann, A. S. (2010). Chapter 12: Culture and Performance. In: The Handbook of Organizational Culture and Climate. (Ashkanasy, N. M., Wilderom, C. P. M., Peterson, M. F., (eds.)), SAGE Publications, Thousand Oaks, Kalifornia, USA. https://doi.org/10.4135/9781483307961.n12

Sathe, V. (1983). Implications of corporate culture: A manager's guide to action. Organizational Dynamics. 12(2), pp. 5-23. https://doi.org/10.1016/0090-2616(83)90030-X

Schein, E. H. (1996). Culture: The Missing Concept in Organizational Studies. Administrative Science Quarterly. 41(2), pp. 229-240. https://doi.org/10.2307/2393715

Schein, E., H. (1990). Organizational culture. American Psychologist. 45(2), pp. 109-119.

https://doi.org/10.1037/0003-066X.45.2.109
Schmidtová, J., Vacek, V. (2013). Applied Statistics. Technical University in Zvolen, Zvolen, Slovakia.

Scholz, C., Bohm, H. (2008). Human Resource Management in Europe: Comparative Analysis and Contextual Understanding. Routledge, Taylor \& Francis Group, New York, USA.

Stacho, Z., Stachová, K. (2013). Talent Management in Organisations Operating in Slovakia. Economic Analls-XXI. 9-10, pp. 53-57. [Online]. Available from: https://www.researchgate.net/publication/283613042_Talent_management_in_organisations_operating_in_slovakia [Accessed: 1st February 2017]

Stopka, O., Bartuška, L., Kampf, R. (2015). Passengers' Evaluation of the Integrated Transport Systems. Naše More. International Journal of Maritime Science \& Technology. 62(3), (Special Issue), pp. 153-157. [Online]. Available from: http://www.nasemore.com/passengers-evaluation-of-the-integrated-transport-systems/ [Accessed: 22nd January 2017]

Stopka, O., Šimková, I. Konečný, V. (2015). The quality of Service in the Public Transport and Shipping Industry. Naše More. International Journal of Maritime Science \& Technology. 62(3), (Special Issue), pp. 126-130. [Online]. Available from: http://www.nasemore.com/the-quality-of-service-in-thepublic-transport-and-shipping-industry/ [Accessed: 20th January 2017]

Suderman, J. (2012). Using the Organizational Cultural Assessment (OCAI) as a Tool for New Team Development. Journal of Practical Consulting. 4(1), pp. 52-58. [Online]. Available from: https://pdfs.semanticscholar. org/3888/ae31c44aec1ff147997c81b0de6e09d3f4ca.pdf [Accessed: 1st February 2017]

Šulgan, M. (2006). Logistics park development in Slovak Republic. Transport. 21(3), pp. 197-200.

Syafii, L. I., Thoyib, A., Nimran, U., Djumahir (2015). The Role of Corporate Culture and Employee Motivation Variable of Leadership Style Related with the Employee Performance (Studies in Perum Perhutani). Procedia - Social and Behavioral Sciences. 211, pp. 1142-1147. https://doi.org/10.1016/j.sbspro.2015.11.152

Trice, H. M., Beyer, J. M. (1993). The cultures of work organizations. Prince Hall, New Jersey, USA.

Turáková, A. (2016). Podniková Kultúra a Analýza Organizačného Charakteru v Slovenských Podnikoch. (Corporate Culture and Analysis of Organizational Character in Slovak Enterprises.), MANEKO: MANažment a EKOnomika. (Journal of MANagament and ECOnomics.) 8(1), pp. 125 136. (in Slovak)

Urbancová, H., Fejfarová, M. (2017). Factors Influencing Age Management in Organisations in the Czech Republic. Acta Universitatis Agriculturae et Silviculturae Mendelianae Brunensis. 65(1), pp. 347-356. https://doi.org/10.11118/actaun201765010347

Vetráková, M., Ďurian, J., Seková, M., Kaščáková, A. (2016). Employee Retention and Development in Pulp and Paper Companies. BioResources. 11(4), pp. 9231-9243. https://doi.org/10.15376/biores.11.4.9231-9243

Weberová, D., Ližbetinová, L. (2016). Consumer attitudes towards Brands in relation to price. In: Proceedings of the 27th International Business Information Management Association Conference - Innovation Management and Education Excellence Vision 2020: From Regional Development Sustainability to Global Economic Growth, IBIMA 2016, Milan, Italy, May 4-5, 2016. pp. 1850-1859.

Wilkins, A., L., Ouchi, W., G. (1983). Efficient Cultures: Exploring the Relationship Between Culture and Organizational Performance. Administrative Science Quaterly. 28(3), pp. 468-481. https://doi.org/10.2307/2392253 